\title{
Performance of Different Planting Density, Organic and Inorganic Sources of Nitrogen on Growth and Yield of Pearlmillet (Pennisetum glaucum L.) in Eastern Region of Uttar Pradesh, India
}

\author{
Kusum Kumari ${ }^{1 *}$, Gautam Ghosh ${ }^{2}$ and Amit Masih ${ }^{3}$ \\ ${ }^{1}$ SHUATS Allahabad, (U.P)-211007, India \\ ${ }^{2}$ Department of Agronomy, ${ }^{3}$ Department of Agriculture Economics, \\ SHUATS Allahabad, (U.P)-211007, India \\ *Corresponding author
}

\author{
A B S T R A C T
}

\begin{tabular}{l} 
Ke y w or d s \\
Planting density, \\
$\begin{array}{l}\text { Organic, } \\
\text { Inorganic, } \\
\text { Pearlmillet. }\end{array}$ \\
Article Info \\
$\begin{array}{l}\text { Accepted: } \\
\text { 26 June } 2017 \\
\text { Available Online: } \\
\text { 10 July } 2017\end{array}$ \\
\hline
\end{tabular}

A field experiment was conducted during the kharif season 2016 at the Crop Research farm of Agronomy, Naini Agricultural Institute, SHUATS, Allahabad (U.P.) to study the effect of organic and inorganic nutrient under different planting density of kharif pearlmillet (Pennisetum glaucum L.). The experiment consisted of three planting density viz., $30 \times 15 \mathrm{cms}, 40 \times 15 \mathrm{cms}, 50 \times 15 \mathrm{cms}$ and four combined application of organic and inorganic sources of nitrogen viz., $100 \%$ RDN $\left(80 \mathrm{~kg} \mathrm{ha}^{-1} \mathrm{~N}, 40 \mathrm{~kg} \mathrm{ha}^{-1} \mathrm{P}, 40 \mathrm{~kg} \mathrm{ha}^{-1}\right.$ $\mathrm{K}), 75 \%$ RDN $\left(80 \mathrm{~kg} \mathrm{ha}^{-1} \mathrm{~N}, 40 \mathrm{~kg} \mathrm{ha}^{-1} \mathrm{P}, 40 \mathrm{~kg} \mathrm{ha}^{-1} \mathrm{~K}\right),+25 \% \mathrm{FYM}, 50 \% \mathrm{RDN}(80 \mathrm{~kg}$ $\left.\mathrm{ha}^{-1} \mathrm{~N}, 40 \mathrm{~kg} \mathrm{ha}^{-1} \mathrm{P}, 40 \mathrm{~kg} \mathrm{ha}^{-1} \mathrm{~K}\right),+50 \%$ FYM, $25 \%$ RDN $\left(80 \mathrm{~kg} \mathrm{ha}^{-1} \mathrm{~N}, 40 \mathrm{~kg} \mathrm{ha}^{-1} \mathrm{P}, 40\right.$ $\left.\mathrm{kg} \mathrm{ha}^{-1} \mathrm{~K}\right),+75 \% \mathrm{FYM}$ was laid out in randomized block design with three replications. The result revealed that treatment $\left(\mathrm{T}_{11}\right) 50 \times 15 \mathrm{cms}+50 \% \mathrm{RDN}+50 \% \mathrm{FYM}$ produced significantly the highest plant height at 60 DAS $(171.59 \mathrm{~cm})$ and 80 DAS $(174.62 \mathrm{~cm})$, dry weight at 20 DAS $\left(0.92 \mathrm{~g} \mathrm{hill}^{-1}\right), 40$ DAS $\left(13.17 \mathrm{~g} \mathrm{hill}^{-1}\right), 60 \mathrm{DAS}\left(71.35 \mathrm{~g} \mathrm{hill}^{-1}\right)$ and 80 DAS $\left(81.79 \mathrm{~g} \mathrm{hill}^{-1}\right)$, grain yield $\left(3.70 \mathrm{t} \mathrm{ha}^{-1}\right)$ and significantly higher length of ear (29.37 $\mathrm{cm})$ and test weight $(12.11 \mathrm{~g})$ respectively. However significantly higher strover yield $\left(8.99 \mathrm{t} \mathrm{ha}^{-1}\right)$ was obtained in treatment $\left(\mathrm{T}_{1}\right) 30 \times 15 \mathrm{cms}+100 \% \mathrm{RDN}\left(80 \mathrm{~kg} \mathrm{ha}^{-1} \mathrm{~N}, 40 \mathrm{~kg}\right.$ ha $\left.^{-1} \mathrm{P}, 40 \mathrm{~kg} \mathrm{ha}^{-1} \mathrm{~K}\right)$.

\section{Introduction}

Pearl millet (Pennisetum glaucum L.) traditionally is an indispensible rainfed cereal crop grown for food and fodder purpose in arid and semi-arid regions. As the crop is hardy can tolerate extreme weather events and changing climatic conditions where other crops generally fail. In India, pearlmillet is popularly known as Bajra (bajri), and it is the fifth most important cereal crop after rice, wheat, maize and sorghum. It has the greatest potential of yield among all the millets.
It is staple food for millions of people in the semi arid tropics. Among agronomical management practices, selection of suitable plant density, organic and inorganic sources of fertilizer and manures (FYM) application (Kumar et al., 2009; Diwedi and Diwedi, 2007; Bhagchand and Gautam, 2000; Kumar et al., 2007) is essential to make best use of limited availability level. In present condition intensive cultivation and increased cropping intensity deplete the soil fertility to some 
extent. Moreover, chemical fertilizers are quite expensive and the small and marginal farmers are unable to use these in required amount. Therefore it is necessary to explore an alternative so that farmer can use the nutrients more efficiently. In the light of these observations, an experiment was laid out to know the effect of planting density, organic and inorganic sources of nitrogen on growth and yield of pearlmillet.

\section{Materials and Methods}

A field experiment was conducted at Crop Research Farm, Department of Agronomy, Naini School of Agriculture, SHUATS, Allahabad (U.P.) India (latitude $25^{\circ} 24^{\prime} 42^{\prime \prime} \mathrm{N}$, longitude $81^{\circ} 50^{\prime} 56^{\prime \prime} \mathrm{E}$ and $98 \mathrm{~m}$ altitude above the mean sea level) on sandy loam soil during kharif season of 2016 to study the effect of planting density, organic and inorganic sources of nitrogen on growth and yield of pearlmillet under U.P. east condition. The climate of the area is semiarid and subtropical. Summers are very hot and winters are very cool. Temperature is high as $40-45{ }^{0} \mathrm{C}$ (May-June) and as low as $6{ }^{\circ} \mathrm{C}$ are experienced. The average rainfall is $550 \mathrm{~mm}$.

The treatment combinations consist of $\mathrm{T}_{1}$ (30 x $15 \mathrm{cms}+100 \%$ RDN i.e. $\mathrm{N}_{80} \mathrm{P}_{40} \mathrm{~K}_{40} \mathrm{~kg}$ ha $\left.{ }^{1}\right), \mathrm{T}_{2}(30 \mathrm{x} 15 \mathrm{cms}+75 \% \mathrm{RDN}$ i.e. $\left.\mathrm{N}_{80} \mathrm{P}_{40} \mathrm{~K}_{40} \mathrm{~kg} \mathrm{ha}^{-1}+25 \% \mathrm{FYM}\right), \mathrm{T}_{3}(30 \times 15$ $\mathrm{cms}+50 \%$ RDN i.e. $\mathrm{N}_{80} \mathrm{P}_{40} \mathrm{~K}_{40} \mathrm{~kg} \mathrm{ha}^{-1}+50$ $\% \mathrm{FYM}), \mathrm{T}_{4}(30 \times 15 \mathrm{cms}+25 \% \mathrm{RDN}$ i.e. $\left.\mathrm{N}_{80} \mathrm{P}_{40} \mathrm{~K}_{40} \mathrm{~kg} \mathrm{ha}^{-1}+75 \% \mathrm{FYM}\right), \mathrm{T}_{5}(40 \times 15$ $\mathrm{cms}+100 \% \mathrm{RDN}$ i.e. $\left.\mathrm{N}_{80} \mathrm{P}_{40} \mathrm{~K}_{40} \mathrm{~kg} \mathrm{ha}^{-1}\right), \mathrm{T}_{6}$ $\left(40 \times 15 \mathrm{cms}+75 \%\right.$ RDN i.e. $\mathrm{N}_{80} \mathrm{P}_{40} \mathrm{~K}_{40} \mathrm{~kg}$ $\left.\mathrm{ha}^{-1}+25 \% \mathrm{FYM}\right), \mathrm{T}_{7}(40 \times 15 \mathrm{cms}+50 \%$ RDN i.e. $\mathrm{N}_{80} \mathrm{P}_{40} \mathrm{~K}_{40} \mathrm{~kg} \mathrm{ha}^{-1}+50 \%$ FYM), $\mathrm{T}_{8}$ $\left(40 \times 15 \mathrm{cms}+25 \%\right.$ RDN i.e. $\mathrm{N}_{80} \mathrm{P}_{40} \mathrm{~K}_{40} \mathrm{~kg}$ $\mathrm{ha}^{-1}+75 \%$ FYM $), \mathrm{T}_{9}(50 \times 15 \mathrm{cms}+100 \%$ RDN i.e. $\left.\mathrm{N}_{80} \mathrm{P}_{40} \mathrm{~K}_{40} \mathrm{~kg} \mathrm{ha}^{-1}\right), \mathrm{T}_{10}(50 \times 15 \mathrm{cms}$ $+75 \%$ RDN i.e. $\mathrm{N}_{80} \mathrm{P}_{40} \mathrm{~K}_{40} \mathrm{~kg} \mathrm{ha}^{-1}+25 \%$ FYM $), \mathrm{T}_{11}(50 \times 15 \mathrm{cms}+50 \%$ RDN i.e. $\left.\mathrm{N}_{80} \mathrm{P}_{40} \mathrm{~K}_{40} \mathrm{~kg} \mathrm{ha}^{-1}+50 \% \mathrm{FYM}\right), \mathrm{T}_{12}(50 \times 15$ $\mathrm{cms}+25 \%$ RDN i.e. $\mathrm{N}_{80} \mathrm{P}_{40} \mathrm{~K}_{40} \mathrm{~kg} \mathrm{ha}^{-1}+75$
$\%$ FYM). The experiment was laid out in randomized block design and replicated thrice. Full dose of farm yard manure (FYM) was applied 11 days before sowing. Half dose of nitrogen through urea as a basal and remaining was top dressed at 30-35 days after sowing. Full dose of phosphorus and potash was applied as diammonium phosphate and muriate of potash at the time of sowing. Pearlmillet was sown in first week of September (due to heavy rainfall) by applying ridge and furrow planting pattern and harvested in second week of December when the crop reached its physiological maturity. The other crop management practices were followed as per standard recommendations. The growth yield attributing character and yield were recorded at harvest.

\section{Statistical analysis}

The data recorded during the course of investigation was subjected to statistical analysis by "Analysis of variance technique', The significant and nonsignificant treatment effects were judged with the help of ' $F$ ' (variance ratio) table. The significant differences between the means were tested against the critical difference at $5 \%$ probability level. Statistical analysis was performed for randomized block design (Gomez et al., 1983). The data generated for one season and analysed statistically.

\section{Results and Discussion}

\section{Effect of growth parameter on pearlmillet}

Data presented in (Table 1) plant height at 60 and 80 DAS, though the significantly higher value recorded was 171.29 and $174.62 \mathrm{~cm}$ in treatment $\mathrm{T}_{11} 50 \mathrm{~cm} \times 15 \mathrm{~cm}+50 \% \mathrm{RDN}+$ $50 \%$ FYM respectively. The increase in the plant height might be due to optimum plant population attributed to minimum intraspecies competition which might help in proper utilization of natural resources i.e. 
space, light, moisture, nutrient uptake and translocation, which ultimately linked with the plant growth and development in terms of plant height. Combined effect of organic (FYM) and inorganic sources of nitrogen released the nutrients probably at faster rate which enriched the soil and providing judicious amount of nutrients that are required to various metabolic processes facilitating faster vegetative growth and leads to higher internodal elongation and finally enhance the plant height (Amgain et al., 2013).

At 60 DAS, higher number of tillers hill ${ }^{-1}$ was recorded in treatment $\mathrm{T}_{11} 50 \mathrm{~cm} \times 15 \mathrm{~cm}+$ $50 \%$ RDN + 50\% FYM (4.20). However, number of tillers hill ${ }^{-1}$ recorded under the treatment $\mathrm{T}_{10} 50 \mathrm{~cm} \times 15 \mathrm{~cm}+75 \% \mathrm{RDN}+$ $25 \%$ FYM was statistically at par to the higher number of tillers hill $^{-1}$. The higher number of tillers hill ${ }^{-1}$ might be attributed to the fact that narrow row spacing intercept more radiation than wider row spacing owing to proper utilization of nutrients as well as moisture under optimum plant population. This may have enabled better vegetative growth leading to higher number of productive tillers hill $^{-1}$ reported by Satyajeet and Nanwal (2007). Application of organic manure with inorganic fertilizer provides greater and prolonged availability of nutrients to crop helps in enhancement of root growth and various biological activity of crop which stimulate rapid cell division and cell elongation for the productive growth of tillers (Amgain et al., 2013).

The plant dry weight (Table 1) at 20, 40, 60 and 80 DAS, observed plant dry weight (0.92, $13.17,71.35$ and $81.79 \mathrm{~g}$ ) showed statistically significantly the highest among treatments under $\mathrm{T}_{11} 50 \mathrm{~cm} \times 15 \mathrm{~cm}+50 \% \mathrm{RDN}+50 \%$ FYM respectively. The increase in dry matter accumulation resulted in greater contribution of photosynthates synthesis to increase in number of tillers and other plant growth attributes (Singh et al., 2014).

\section{Yield attributes and yield of pearlmillet}

The data revealed that (Table 2) there was an increase in grain yield. Treatment $\mathrm{T}_{11}(50 \times 15$ cms $+50 \%$ RDNi.e. $\mathrm{N}_{80} \mathrm{P}_{40} \mathrm{~K}_{40} \mathrm{~kg} \mathrm{ha}^{-1}+50 \%$ FYM), recorded significantly highest value $\left(3.70 \mathrm{t} \mathrm{ha}^{-1}\right)$ of grain yield, which was $51.64 \%$ higher than lowest grain yield $\left(2.44 \mathrm{t} \mathrm{ha}^{-1}\right)$ observed in $\mathrm{T}_{4}(50 \times 15 \mathrm{cms}+25 \% \mathrm{RDN}$ i.e. $\mathrm{N}_{80} \mathrm{P}_{40} \mathrm{~K}_{40} \mathrm{~kg} \mathrm{ha}^{-1}+75 \%$ FYM). Application of organic and inorganic nutrient sources with optimum spacing of plants significantly enhanced the grain yield might be due to improvement in yield attributes (ear length, test weight etc.) which also necessary for sustaining higher productivity of pearlmillet (Priyadarshani et al., 2012; Jat et al., 2013).

The data revealed that (Table 2) there was an increase in stover yield. Treatment $\mathrm{T}_{1}(30 \mathrm{x}$ $15 \mathrm{cms}+100 \%$ RDNi.e. $\mathrm{N}_{80} \mathrm{P}_{40} \mathrm{~K}_{40} \mathrm{~kg} \mathrm{ha}^{-1}$ ), recorded significantly higher value (8.99 $\mathrm{t}$ ha ${ }^{1}$ ) of stover yield, which was $36.00 \%$ higher than the lowest stover yield (6.61 $\left.\mathrm{t} \mathrm{ha}^{-1}\right)$ observed in $\mathrm{T}_{12}(50 \times 15 \mathrm{cms}+50 \%$ RDNi.e. $\mathrm{N}_{80} \mathrm{P}_{40} \mathrm{~K}_{40} \mathrm{~kg} \mathrm{ha}{ }^{-1}+50 \%$ FYM). However, Treatment $\mathrm{T}_{5}(40 \times 15 \mathrm{cms}+100 \%$ RDNi.e. $\left.\mathrm{N}_{80} \mathrm{P}_{40} \mathrm{~K}_{40} \mathrm{~kg} \mathrm{ha}^{-1}\right)$ was found statistically to be on a par with $\mathrm{T}_{1}(30 \times 15$ $\mathrm{cms}+100 \%$ RDN i.e. $\mathrm{N}_{80} \mathrm{P}_{40} \mathrm{~K}_{40} \mathrm{~kg} \mathrm{ha}^{-1}$ ).

An increase in stover yield owing to fertilizer application through organic and inorganic sources of nutrients might be because of increased plant height and profuse tillering (Jat et al., 2013). Data pertaining to earhead length showed that significantly higher value $(29.37 \mathrm{~cm})$ of ear length was observed in treatment $\mathrm{T}_{11}(50 \mathrm{x} 15 \mathrm{cms}+50 \%$ RDNi.e. $\mathrm{N}_{80} \mathrm{P}_{40} \mathrm{~K}_{40} \mathrm{~kg} \mathrm{ha}^{-1}+50 \%$ FYM) which was found $12.70 \%$ higher than the lowest value observed. 
Table.1 Effect of different planting density, organic and inorganic sources of nitrogen on growth attributes of Pearlmillet (Pennisetum glaucum L.)

\begin{tabular}{|c|c|c|c|c|c|c|c|c|}
\hline \multicolumn{2}{|c|}{ Treatment Combinations } & \multicolumn{2}{|c|}{ Plant height (cm) } & \multirow{2}{*}{ 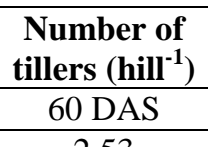 } & \multicolumn{4}{|c|}{ Dry weight of plant (g hill ${ }^{-1}$ ) } \\
\hline & & $60 \mathrm{DAS}$ & $80 \mathrm{DAS}$ & & $20 \mathrm{DAS}$ & 40 DAS & $60 \mathrm{DAS}$ & $80 \mathrm{DAS}$ \\
\hline $\mathbf{T}_{1}$ & $30 \mathrm{~cm} \times 15 \mathrm{~cm}+100 \% \mathrm{RDN}$ & 160.20 & 165.86 & 2.53 & 0.85 & 10.55 & 66.14 & 76.43 \\
\hline $\mathbf{T}_{2}$ & $\begin{array}{l}30 \mathrm{~cm} \times 15 \mathrm{~cm}+75 \% \mathrm{RDN}+25 \% \\
\text { FYM }\end{array}$ & 165.17 & 171.18 & 2.73 & 0.79 & 11.69 & 69.33 & 78.18 \\
\hline $\mathbf{T}_{3}$ & $\begin{array}{l}30 \mathrm{~cm} \times 15 \mathrm{~cm}+50 \% \mathrm{RDN}+50 \% \\
\text { FYM }\end{array}$ & 168.37 & 157.77 & 3.27 & 0.83 & 12.73 & 70.01 & 79.53 \\
\hline $\mathbf{T}_{4}$ & $\begin{array}{l}30 \mathrm{~cm} \times 15 \mathrm{~cm}+25 \% \mathrm{RDN}+75 \% \\
\text { FYM }\end{array}$ & 156.51 & 157.10 & 2.33 & 0.72 & 10.00 & 62.38 & 75.17 \\
\hline $\mathbf{T}_{5}$ & $40 \mathrm{~cm} \times 15 \mathrm{~cm}+100 \% \mathrm{RDN}$ & 163.71 & 167.48 & 2.60 & 0.78 & 10.86 & 67.11 & 77.08 \\
\hline $\mathbf{T}_{6}$ & $\begin{array}{l}40 \mathrm{~cm} \times 15 \mathrm{~cm}+75 \% \mathrm{RDN}+25 \% \\
\mathrm{FYM}\end{array}$ & 166.39 & 172.96 & 3.07 & 0.86 & 11.84 & 69.67 & 78.29 \\
\hline $\mathbf{T}_{7}$ & $\begin{array}{l}40 \mathrm{~cm} \times 15 \mathrm{~cm}+50 \% \mathrm{RDN}+50 \% \\
\text { FYM }\end{array}$ & 169.23 & 159.25 & 3.47 & 0.91 & 12.79 & 70.34 & 80.24 \\
\hline $\mathbf{T}_{8}$ & $\begin{array}{l}40 \mathrm{~cm} \times 15 \mathrm{~cm}+25 \% \mathrm{RDN}+75 \% \\
\text { FYM }\end{array}$ & 159.36 & 164.86 & 2.40 & 0.71 & 10.00 & 64.72 & 76.38 \\
\hline $\mathbf{T}_{\mathbf{9}}$ & $50 \mathrm{~cm} \times 15 \mathrm{~cm}+100 \% \mathrm{RDN}$ & 166.54 & 173.21 & 2.73 & 0.79 & 11.39 & 67.76 & 77.42 \\
\hline $\mathbf{T}_{10}$ & $\begin{array}{l}50 \mathrm{~cm} \times 15 \mathrm{~cm}+75 \% \mathrm{RDN}+25 \% \\
\mathrm{FYM}\end{array}$ & 171.12 & 171.29 & 3.60 & 0.89 & 12.95 & 70.78 & 81.34 \\
\hline $\mathbf{T}_{11}$ & $\begin{array}{l}50 \mathrm{~cm} \times 15 \mathrm{~cm}+50 \% \mathrm{RDN}+50 \% \\
\mathrm{FYM}\end{array}$ & 171.59 & 174.62 & 4.20 & 0.92 & 13.17 & 71.35 & 81.79 \\
\hline $\mathbf{T}_{12}$ & $\begin{array}{l}50 \mathrm{~cm} \times 15 \mathrm{~cm}+25 \% \mathrm{RDN}+75 \% \\
\text { FYM }\end{array}$ & 166.77 & 167.88 & 3.13 & 0.89 & 12.19 & 69.72 & 76.43 \\
\hline \multicolumn{2}{|c|}{$\mathrm{F}-$ test } & $\mathrm{S}$ & $\mathrm{S}$ & $\mathrm{S}$ & $\mathrm{S}$ & $\mathrm{S}$ & $\mathrm{S}$ & $\mathrm{S}$ \\
\hline \multicolumn{2}{|c|}{ S. Ed. ( $(\underline{)})$} & 0.87 & 0.80 & 0.36 & 0.04 & 0.21 & 0.92 & 0.96 \\
\hline \multicolumn{2}{|c|}{$\mathrm{CD}(0.05 \%)$} & 1.81 & 1.66 & 0.74 & 0.09 & 0.43 & 1.90 & 2.00 \\
\hline
\end{tabular}


Table.2 Effect of different planting density, organic and inorganic sources of nitrogen on yield and yield attributes of pearlmillet (Pennisetum glaucum L.)

\begin{tabular}{|c|c|c|c|c|c|}
\hline \multicolumn{2}{|c|}{ Treatment Combinations } & \multirow{2}{*}{$\begin{array}{c}\begin{array}{c}\text { Length of } \\
\text { earhead }(\mathbf{c m})\end{array} \\
26.06\end{array}$} & \multirow{2}{*}{$\begin{array}{c}\text { Test weight (g) } \\
2.68\end{array}$} & \multirow{2}{*}{$\begin{array}{c}\text { Grain yield }\left(\mathbf{t ~ h a}^{-\mathbf{1}}\right) \\
2.68\end{array}$} & \multirow{2}{*}{$\begin{array}{c}\text { Stover yield (t ha } \\
\mathbf{1}) \\
8.99\end{array}$} \\
\hline $\mathbf{T}_{1}$ & $30 \mathrm{~cm} \times 15 \mathrm{~cm}+100 \% \mathrm{RDN}$ & & & & \\
\hline $\mathbf{T}_{2}$ & $30 \mathrm{~cm} \times 15 \mathrm{~cm}+75 \% \mathrm{RDN}+25 \% \mathrm{FYM}$ & 27.65 & 2.79 & 2.79 & 8.77 \\
\hline $\mathbf{T}_{3}$ & $30 \mathrm{~cm} \times 15 \mathrm{~cm}+50 \% \mathrm{RDN}+50 \% \mathrm{FYM}$ & 28.49 & 2.85 & 2.85 & 8.06 \\
\hline $\mathbf{T}_{4}$ & $30 \mathrm{~cm} \times 15 \mathrm{~cm}+25 \% \mathrm{RDN}+75 \% \mathrm{FYM}$ & 27.21 & 2.44 & 2.44 & 7.14 \\
\hline $\mathbf{T}_{5}$ & $40 \mathrm{~cm} \times 15 \mathrm{~cm}+100 \% \mathrm{RDN}$ & 26.66 & 2.92 & 2.92 & 8.90 \\
\hline $\mathbf{T}_{6}$ & $40 \mathrm{~cm} \times 15 \mathrm{~cm}+75 \% \mathrm{RDN}+25 \% \mathrm{FYM}$ & 28.23 & 2.98 & 2.98 & 8.25 \\
\hline $\mathbf{T}_{7}$ & $40 \mathrm{~cm} \times 15 \mathrm{~cm}+50 \% \mathrm{RDN}+50 \% \mathrm{FYM}$ & 28.53 & 3.15 & 3.15 & 7.95 \\
\hline $\mathbf{T}_{8}$ & $40 \mathrm{~cm} \times 15 \mathrm{~cm}+25 \% \mathrm{RDN}+75 \% \mathrm{FYM}$ & 27.43 & 2.51 & 2.51 & 7.08 \\
\hline $\mathbf{T}_{9}$ & $50 \mathrm{~cm} \times 15 \mathrm{~cm}+100 \% \mathrm{RDN}$ & 27.41 & 3.30 & 3.30 & 7.38 \\
\hline $\mathbf{T}_{10}$ & $50 \mathrm{~cm} \times 15 \mathrm{~cm}+75 \% \mathrm{RDN}+25 \% \mathrm{FYM}$ & 29.15 & 3.28 & 3.28 & 7.07 \\
\hline $\mathbf{T}_{11}$ & $50 \mathrm{~cm} \times 15 \mathrm{~cm}+50 \% \mathrm{RDN}+50 \% \mathrm{FYM}$ & 29.37 & 3.70 & 3.70 & 6.61 \\
\hline $\mathbf{T}_{12}$ & $50 \mathrm{~cm} \times 15 \mathrm{~cm}+25 \% \mathrm{RDN}+75 \% \mathrm{FYM}$ & 28.29 & 2.55 & 2.55 & 2.55 \\
\hline \multicolumn{2}{|c|}{$\mathrm{F}$ - test } & $\mathrm{S}$ & $\mathrm{S}$ & $\mathrm{S}$ & $\mathrm{S}$ \\
\hline \multicolumn{2}{|c|}{ S. Ed. $( \pm)$} & 0.20 & 0.10 & 0.13 & 0.09 \\
\hline \multicolumn{2}{|c|}{$\mathrm{CD}(0.05 \%)$} & 0.41 & 0.22 & 0.27 & 0.18 \\
\hline
\end{tabular}


However treatment $\mathrm{T}_{10}(50 \times 15 \mathrm{cms}+75 \%$ RDNi.e. $\mathrm{N}_{80} \mathrm{P}_{40} \mathrm{~K}_{40} \mathrm{~kg} \mathrm{ha}^{-1}+25 \%$ FYM) was at par with treatment $\mathrm{T}_{11}(50 \mathrm{x} 15 \mathrm{cms}+50 \%$ RDNi.e. $\mathrm{N}_{80} \mathrm{P}_{40} \mathrm{~K}_{40} \mathrm{~kg} \mathrm{ha}^{-1}+50 \%$ FYM).

The probable reason for increases length of ear might be due to cumulative effect of growth and vigour of plants leads to increase supply of metabolites which have significant effect on growth character and yield attributes and also higher rate of photosynthesis as well as higher translocation of photosynthates from various plant organs to the development of ear length (Kumar et al., 2015).

Treatment $\mathrm{T}_{11}(50 \times 15 \mathrm{cms}+50 \%$ RDNi.e. $\mathrm{N}_{80} \mathrm{P}_{40} \mathrm{~K}_{40} \mathrm{~kg} \mathrm{ha}{ }^{-1}+50 \%$ FYM) registered maximum value $(12.11 \mathrm{~g})$ of test weight which was $22.81 \%$ higher than the lowest test weight $(9.86 \mathrm{~g})$ recorded in treatment $\mathrm{T}_{4}(30 \times 15 \mathrm{cms}+25 \% \mathrm{RDN}$ i.e. $\left.\mathrm{N}_{80} \mathrm{P}_{40} \mathrm{~K}_{40} \mathrm{~kg} \mathrm{ha}^{-1}+75 \% \mathrm{FYM}\right)$. However, treatment $\mathrm{T}_{10}(50 \mathrm{x} 15 \mathrm{cms}+75 \%$ RDNi.e. $\mathrm{N}_{80} \mathrm{P}_{40} \mathrm{~K}_{40} \mathrm{~kg} \mathrm{ha}^{-1}+25 \%$ FYM) was found statistically at par with $\mathrm{T}_{11}(50 \times 15 \mathrm{cms}$ $+50 \%$ RDN i.e. $\mathrm{N}_{80} \mathrm{P}_{40} \mathrm{~K}_{40} \mathrm{~kg} \mathrm{ha}^{-1}+50 \%$ FYM) (Table 2).

An increase in test weight might be due to significant improvement in growth character and better mobilization of nutrients throughout the growth period which might have provided stability in higher supply of photosynthates towards the sink (grain/ear) revealed by Jat et al., (2013).

It may be concluded that amongst all the treatments, treatment $\mathrm{T}_{11}(50 \times 15 \mathrm{cms}+50 \%$ RDN i.e. $\mathrm{N}_{80} \mathrm{P}_{40} \mathrm{~K}_{40} \mathrm{~kg} \mathrm{ha}^{-1}+50 \%$ FYM) has been found to be the best for obtaining the highest growth attributes, yield attributes and yield of pearlmillet (Pennisetum glaucum L.). Since the findings are based on the research done in one season, it may be repeated for confirmation.

\section{References}

Amgain, L.P. Sharma, A.R. Das, T.K. and Behera, V.K. 2013. Effect of residue management on productivity and economics of pearlmillet based cropping system under zero-till condition. Indian J. Agron., 58(3): 298302.

Choudhary, R.S. and Gautam, R.C. 2006. Influence of cropping systems and nutrient management on nutrient uptake, protein content, yield, productivity and net return of pearlmillet. Annals of Agri. Res., 27: 302-305.

Gomez, A.K. and Gomez, A.A. 1983. Statistical Procedure for Agricultural Research, 2 ${ }^{\text {nd }}$ Ed., p 680. John Wiley and Sons.

Jat, M.K., Purohit, H.S., Singh, B., Garhwal, R.S. and Choudhary, M. 2013. Effect of integrated nutrient management on yield and nutrient uptake in sorghum (Sorghum bicolor. Indian J. Agron., 58(4): 543-547.

Kumar, A. Rana, K.S. Rana, D.S. Bana, R.S. Choudhary, A.K. and Pooniya, V. 2015. Effect of nutrient and moisture management practices on crop productivity, water-use efficiency and energy dynamics in rainfed maize (Zea mays L.)+soyabean (Glycine $\max \mathrm{L}$ ). intercropping system. Indian J. Agron., 60(1): 152-6.

Kumar, Pawan and Nanwal, R.K. 2006. Effect of integrated nutrient supply on the productivity and soil health under pearlmillet-wheat cropping sequence. $J$. Maharastra Agri. Univ., 31: 7-9.

Parihar, C.M., Kaushik, M.K. and Palsaniya, D.R. 2005. Effect of varieties, plant density and phosphorus levels on growth and yield of clusterbean (Cyamopsis tetragonoloba L). Annals of Agri. Res., 26 (1): 5-7. 
Pathan, A.R.K. and Nag, A.K. 2010. Production potential and economic of synthesized sustainable model of pearlmillet-wheat crop sequence. Annals of Plant and Soil Res., 12(1): 56-58.

Priyadarshani, Khambalkar, A., Tomar, P.S. and Verma, S.K. 2012. Long term effect of integrated nutrient management on productivity and soil fertility in pearlmillet (Pennisetum glaucum)mustard (Brassica juncea). cropping sequence. Indian J. Agron., 57(3): 222228.

Ranveer Singh, Gupta, A.K., Tulasa Ram, Chodhary, G.L. and Sheoran, A.C. 2013. Effect of integrated nutrient management on transplanted pearlmillet (Pennisetum glaucum. under rainfed condition. Indian J. Agron., 58: 81-85.
Rathore, B.S., Rana, V.S. and Nanwal, R.K. 2007. Effect of plant density and fertility levels on growth and yield of pearlmillet (Pennisetum glaucum. hybrids under limited irrigation condition in semi-arid environment. Indian J. Agri. Sci., 78(8): 667-70.

Rathore, S.S. and Gautam, R.C. 2003. Agrotechniques to improve the productivity of pearlmillet (Pennisetum glaucum. + cowpea intercropping system under dryland conditions. Annals of Agri. Res., New series. 24(4): 971-975.

Sant Bahadur Singh and S.K. Chauhan. 2013. Productivity and economics of pearlmillet as influenced by integrated nutrient management. Annals of Plant and Soil Res, 16(4): 356-358.

\section{How to cite this article:}

Kusum Kumari, Gautam Ghosh and Amit Masih. 2017. Performance of Different Planting Density, Organic and Inorganic Sources of Nitrogen on Growth and Yield of Pearlmillet (Pennisetum glaucum L.) In Eastern Region of Uttar Pradesh, India. Int.J.Curr.Microbiol.App.Sci. 6(7): 2525-2531. doi: https://doi.org/10.20546/ijcmas.2017.607.357 